\title{
Rekomendasi Rute Perjalanan Wisata Berbasis Web Menggunakan Algoritma Genetika
}

\author{
I Putu Gede Hendra Suputra ${ }^{1}$, Cokorda Rai Adi Pramartha ${ }^{2}$ \\ 1Jurusan Teknik Informatika, Fakultas MIPA, Universitas Udayana \\ Denpasar, Indonesia \\ hendra.suputra@unud.ac.id \\ ${ }^{2}$ Cokorda Rai Adi Pramartha \\ 2 Jurusan Teknik Informatika, Fakultas MIPA, Universitas Udayana \\ Denpasar, Indonesia \\ cokorda@unud.ac.id
}

\begin{abstract}
Abstrak
Perkembangan dan kemajuan di dunia teknologi informasi membuat salah perkembangan dunia pariwisata khususnya Bali semakin maju. Sampai sejauh ini perkembangan pariwisata di Bali tidak terlepas dari penggunaan konsep E-Tourism sebagai media penyebarluasan dan promosi informasi wisata. Banyak situs-situs yang tersedia di internet (dimiliki swasta atau pemerintah) menjadi media informasi dan media pemesanan akomodasi wisata. Namun situs-situs tersebut dapat dikatakan masih bersifat statis dan sederhana. Para penyedia tersebut hanya menyediakan informasi secara tertulis tanpa mengedepankan sisi responsiveness dan interactivity kepada pengguna. Responsiveness dan interactivity adalah sesuatu yang masih kurang dalam pembangunan situs-situs wisata di Indonesia. Situs-situs hanya menampilkan informasi dan tidak dapat merespon dan berinteraksi langsung dengan kebutuhan khusus pengguna seperti agenda perjalanan wisata. Permasalah tersebut telah diatasi sebelumnya), prototipe yang dibangun telah mempu memberikan rekomendasi sesuai dengan kebutuhan pengguna, namun pada sistem yang dibangun tersebut masih memiliki kelemahan yaitu sistem akan menghasilakan terlalu banyak rekomendasi (kurang optimal karena sebenarnya tidak semua sesuai) mengingat banyaknya jumlah wisata yang ada dan membuang waktu komputasi. Pada penelitian ini akan ditambahkan kriteria mengenasi prioritas tempatjjenis wisata yang ingin dikunjungi dan tempat/lokasi wisata yang tidak ingin dikunjungi. Kriteria-kriteria tersebut diolah pada Algoritma Genetika dan telah mampu menghasilkan hasil penjadwalan rute yang lebih akurat dan optimal sesuai kriteria.
\end{abstract}

Keywords - Sistem Informasi, E-Toursim, Penjadwalan Rute Wisata, Genetika

\section{Pendahuluan}

Pergi melepas lelah setelah berkerja keras terus-menerus telah menjadi gaya hidup masyarakat modern saat ini. Cara yang dipilih tentu saja beragam mulai dari berwisata hanya beberapa jam hingga menginap berhari-hari baik di tempat yang sudah pernah dikunjungi maupun tempat yang baru. Wisatawan biasanya merencakan segala kegiatan wisata tersebut melalui agen wisata hingga menggunakan aplikasi wisata secara mandiri. Kemajuan dunia teknologi informasi sangat berpengaruh pesat terhadap perkembangan dunia pariwisata baik dari sisi pemasaran maupun sisi fasilitas wisata. Banyak daerah-daerah wisata yang semakin berkembang secara pesat salah satunya adalah provinsi Bali.

Perkembangan dan kemajuan di dunia teknologi informasi membuat perkembangan dunia pariwisata khususnya Bali semakin maju. E-Tourism mulai diperkenalkan secar luas dan digunakan secara besar-besaran dalam hal penyebarluasan informasi dan pemasaran destinasidestinasi wisata. Banyak situs yang tersedia yang berfungsi sebagai media informasi hingga media pemesanan akomodasi wisata yang dimiliki oleh pemerintah maupun swasta. Namun situs-situs tersebut dinilai masih banyak yang bersifat statis dan sederhana. Para penyedia situssitus tersebut menyediakan informasi wisata secara tertulis tanpa mengedepankan sisi 
responsiveness dan interactivity terhadap kebutuhan pengguna. Kedua hal tersebut menjadi suatu kekurangan pada situs-situs wisata yang ada di Indonesia [1]. Situs-sistus wisata yang dibangun hanya memberikan informasi-informasi dan tidak merespon secara interaktif terhadap kebutuhan pengguna. Kebutuhan yang dimaksud adalah kebutuhan khusus yang diinginkan seorang pengguna terhadap perjalanan wisata yang dilakukannya. Kebutuhan tersebut dapat berupa penjadwalan wisata sesuai kriteria-kriteria yang wisatawan misalnya ingin pergi ke pantai, ke pasar tradisional, ingin menikmati wisata pegunungan, pasar tradisional dan seagainya.

Permasalahan situs wisata terkait responsiveness dan interactivity telah coba diatasi pada penelitian sebelumnya [2]. Dimana pada penelitian tersebut dihasilkan sebuah prototipe pemenuhan kebutuhan wisatawan dengan memberikan rekomendasi berdasarkan kriteria yang dipilih di awal. Sistem tersebut memang dapat menghasilkan rekomendasi berdasarkan kriteria yang ada, namun belum mampu memberikan nilai prioritas pada suatu jenis/lokasi destinasi tertentu dan memberikan keterangan tentang jenis/lokasi destinasi yang tidak ingin dikunjungi selama berwisata. Hal tersebut penting diberikan kepada pengguna untuk membatasi sistem dalam membangkitkan rute-rute perjalanan yang memang benar-benar sesuai dengan kebutuhan pengguna. Optimasi tersebut akan memberikan hasil yang lebih akurat (hanya menampilkan hasil yang terbaik) dan akan menghemat waktu komputasi sistem.

Melihat dari permasalahan tersebut peneliti ingin mengembangkan sebuah sistem yang mampu memberikan suatu penjadwalan rute perjalanan wisata di daerah Bali. Pengguna akan diberikan sebuah penjadwalan rute perjalanan wisata yang terdiri dari rute perjalan wisata dan waktu kunjungan wisata yang sesuai dengan kebutuhan/syarat-syarat dari pengguna itu sendiri. Sistem tersebut akan dibangun berbasis web dengan mengkombinasikan teknologi Google Maps API dan Algoritma Genetika. Algoritma genetika sebenarnya sudah pernah diteliti sebelumnya dalam penelitian [3] namun pada penelitian tersebut hanya difokuskan pada masalah TSP (travelling salesman problem) tanpa adanya kriteria tertentu yang menjadi spesifikasi kebutuhan user. Sedangkan pada peneltiian ini algoritma Genetika digunakan sebagai generator pembuat jadwal rute perjalanan berdasarkan kombinasi kriteria yang dimasukan oleh Pengguna mulai dari tempat mulai perjalanan, tempat berhenti, banyaknya waktu yang dimiliki, kategori wisata yang dikunjungi, tempat/jenis wisata yang menjadi prioritas dan tempat/jenis wisata yang tidak ingin dikunjungi.

\section{Metode Penelitian}

\subsection{Data}

Data yang digunakan dalam penelitian ini diambil dari situs-situs wisata pada internet, artikel-artikel wisata yang terdapat pada internet secara bebas. Selain dari pada itu data juga diambil dari situs-situs resmi pemerintah provinsi bali yang berkaitan dengan pariwisata. Setiap destinasi wisata yang telah tersimpan selanjutnya diberikan label (tag) yang berkaitan dengan destinasi wisata tersebut. Selain menyimpan data, pada penelitian ini juga disimpan koordinat dari masing-masing destinasi sesuai dengan apa yang tercatat pada Google Maps API yaitu nilai dari latitude dan longitude. Selain hal tersebut semua destinasi wisata yang ada memiliki nilai rating tertentu (1-5) yang diadaptasikan dari beberapa situs-situs wisata. Hal tersebut dijadikan acuan untuk menghitung jarak dan waktu yang terdapat diantara dua destinasi wisata.

\subsection{Implementasi Algoritma Genetika}

Algoritma Genetika adalah bagian dari metode heuristic yang digunakan untuk mencari solusi optimal pada suatu permasalahan tertentu dengan menggunakan teknik pencarian yang menyerupai proses evolusi mahluk hidup [4] [5]. Dalam proses pencarian tersebut algoritma Genetika menggunakan mekanisme pencarian secara acak dan juga terstruktur. Berikut beberapa definisi penting yang perlu diperhatikan di mendefinisikan individu untuk membangun penyelesaian permasalahan dengan algoritma Genetika adalah sebagai berikut [6]:

1. Genotype representasi nilai dari satuan dasar dari genotype yaitu kromosom. Genotype dapat berupa suatu biner, float, karakter, kombinatorial dan lain sebagianya.

2. Allele adalah representasi nilai dari suatu Genotype.

3. Kromosom ialah kumpulan dari Genotype yang tersususun membentuk suatu nilai-nilai tertentu. 
4. Individu adalah sesuatu yang digunakan untuk menyatakan suatu keadaan datu salah satu solusi yang diharapkan. Individu tersusun dari sususan kromosom.

5. Populasi adalah kelompok atau kumpulan individu yang diproses pada suatu siklus tertentu.

6. Generasi adalah satuan untuk menyatakan satu siklus evolusi atau iterasi pada algoritma genetika.

Berikut adalah alur umum proses pencarian solusi optimal dari algoritma genetika [7] sesuai dengan Gambar 1.

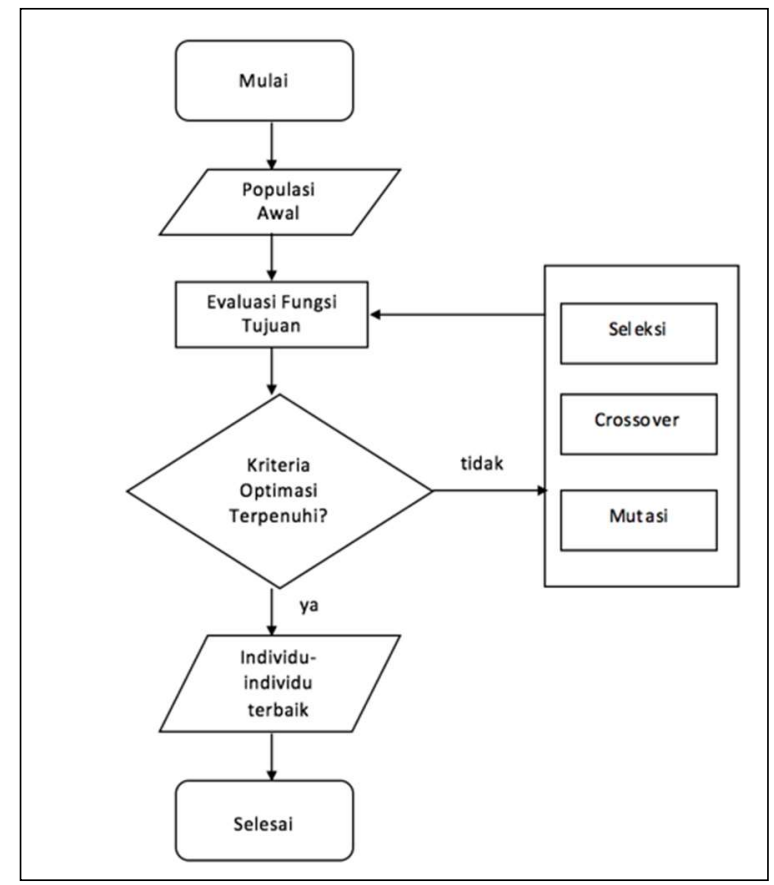

Gbr 1. Alur Algoritma Genetika

Algoritma genetika pada sistem ini digunakan sebagai generator utama untuk membentuk rute perjalanan wisata terbaik. Langkah-langkah yang dilakukan dalam proses penyusunan rute tersebut adalah sebagai berikut sesuai dengan Gambar 1:

1. Sistem menerima input-input destinasi dan beberapa kriteria tertentu. Selanjutnya dilakukan filter berdasarkan kategori destinasi yang dipilih dan tag-tag destinasi yang dipilih oleh pengguna.

2. Input-input destinasi yang terpilih selanjutnya menjadi kromosom pada algoritma Genetika. Setiap kromosom membentuk individu. Dalam kasus ini, panjang susunan kromosom setiap individu dibuat berbeda dengan yang lainnya. Karena setiap individu tersusun atas kromosom yang sangat dipengaruhi oleh kriteria yang diinputkan oleh pengguna pada sistem. Suatu kriteria tertentu dapat membentuk berbagai kombinasi wisata yang sesuai. Hal tersebut disebabkan oleh karena setiap destinasi wisata memiliki tag (kategori) lebih dari satu, sehingga memungkinkan jumlah destinasi yang direkomendasikan untuk suatu rute perjalanan beragam. Individu tersebut direpresentasikan pada Tabel 1.

Tabel 1. Contoh Susunan Kromosom untuk setiap individu

\begin{tabular}{ll}
\hline Individu & Susunan Kromosom \\
\hline T1 & D1 D2 D6 D4 D7 \\
\hline T2 & D2 D8 D3 D4 \\
\hline T3 & D3 D2 D10 D4 D5 \\
\hline T4 & D2 D5 D6 D7 \\
\hline
\end{tabular}


T1 merepresentasikan trip (rute Perjalanan) dan D1, D2 dst adalah representasi dari destinasi-destinasi wisata yang ada. Dimana urutannya susunan tersebut juga mrerepesentasi urutan destinasi yang akan dikunjungi.

3. Individu dibangkitkan sebanyak maks 100 atau maks jumlah kombinasi dari destinasi yang telah difilter sebelumnya sesuai kriteria.

4. Setiap individu diuji berdasarkan nilai fitness (Fungsi Tujuan) yang terbentuk. Nilai fitnes ditentukan berdasarkan persamaan (1) berikut:

$$
\text { Fitness }_{i}=\frac{1}{I R_{i} \times I W P_{i} \times I B T_{i}}
$$

dimana

$I R_{i}$ adalah Indeks Rating destinasi Rute Wisata ke-I, $I W P_{i}$ adalah Indeks Waktu Perjalanan Rute Wisata ke-I, dan IBT $T_{i}$ adalah (Indeks Best Time) adalah kesesuaian waktu kunjungan terbaik untuk setiap destinasi pada suatu Rute Wisata ke-i. jika datang pada saat yang tepat maka nilai btji $=1$ sedangkan jika tidak maka $=0$.

$$
\begin{aligned}
& I R_{i}=\frac{n \times M A X(R t)}{\sum_{j=1}^{n} R t_{i j}} \\
& I W P_{i}=\frac{T W i s_{i}}{T W i s_{i}-T J l n_{i}}
\end{aligned}
$$

IBT (Indeks Best Time),

$$
I B T_{i}=\frac{n \times \sum_{j=1}^{n} B T_{i j}}{n^{2}}
$$

5. Selah setiap individu memiliki nilai fitness maka langkah selanjutnya adalah mencari individu baru berdasarkan crossover dan mutasi sesuai nilai peluang pada roulete wheel yang didapat dari nilai fitness.

6. Individu yang terbaik disimpan disetiap generasi dan setelah semua iterasi selesai maka selanjutnya hanya ditampilkan beberapa individu yang terbaik pada halaman pembangkitan rute perjalanan wisata pada sistem.

\section{Hasil dan Diskusi}

\subsection{Implementasi Sistem Rekomendasi Rute Wisata}

Aplikasi dikembangkan dalam media website informasi wisata. Menu utama dari aplikasi yang dibangun adalah input rute wisata dan halaman hasil rekomendasi menggunakan Algoritma Genetika. Pada menu input rute wisata pengguna menginputkan kapan akan pergi, berapa banyak destinasi yang akan dikunjungi, menginputkan destinasi sebagai titik awal, waktu pukul berapa akan berangkat, menginputkan berapa banyak waktu (dalam jam) yang pengguna akan habiskan dalam perjalanannya, menginputkan tag-tag dari tempat wisata lalu selanjutnya menekan tombol create lalu sistem akan memproses dan menampilkan rekomendasi rute perjalanan wisata. Pada tampilan awal Pengguna akan langsung ditampilan pada beberapa menu yaitu menu Home, Tempat wisata, rute wisata dan search. Pengguna tidak harus login jika ingin menggunakan sistem ini. Sistem ini dapat diakses secara bebas. Semua menu yang disajikan dihalaman utama adalah menu yang dapat diakses walaupun pengguna tidak registrasi. 


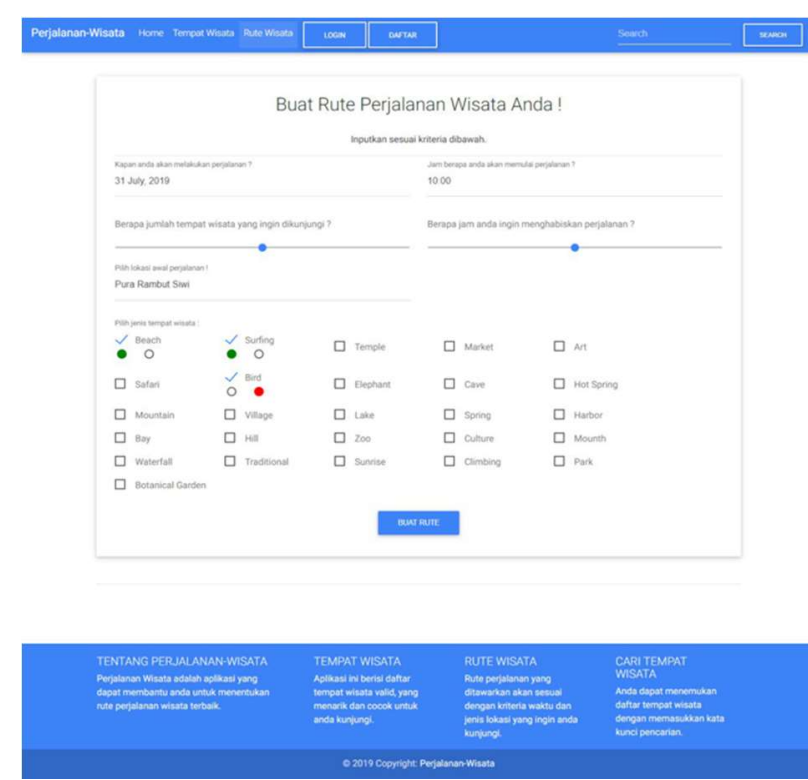

Gambar 2. Tampilan Halaman input Rute Wisata

Gambar 2 merupakan tampilan halaman input rute wisata dimana Pengguna menginputkan beberapa syarat perjalanan wisata yaitu menginputkan kapan akan pergi, berapa banyak destinasi yang akan di kunjungi, menginputkan destinasi sebagai titik start awal, pukul waktu keberangkatan, menginputkan berapa banyak waktu yang pengguna akan habiskan dalam perjalanannya dan menginputkan tag-tag destinasi wisata. Setelah itu semua, maka sistem akan memberikan rekomendasi jalur perjalanan wisata.

\subsection{Hasil Rekomendasi Menggunaan Algoritma Genetika}

Pada Gambar 3. dapat dilihat bahwa terdapat pembentukan rute perjalanan wisata dengan berbagai kombinasi susunan alur destinasi. Rute ditentukan berdasarkan perhitungan jarak destinasi, tag-tag yang terpilih, dan lama perjalanan. Selanjutnya mungkin ada beberapa rute, namun untuk menentukan rekomendasi paling bagus ditentukan dengan algoritma genetika yang digenerasikan berdasarkan nilai fitnes dari Persamaan 1. Individu yang terbaik yang menghasilkan generasi rute-rute terbaik pula. Dengan model banyaknya syarat yang dimasukan dan perhitungan nilai fitnes yang ketat dimungkinkan bahwa mengurangi alternatif rute sehingga penyampaian informasi rute lebih efektif dan efisien. Hal ini berpotensi membantu pengguna mendapatkan informasi yang lebih akurat dan sesuai.

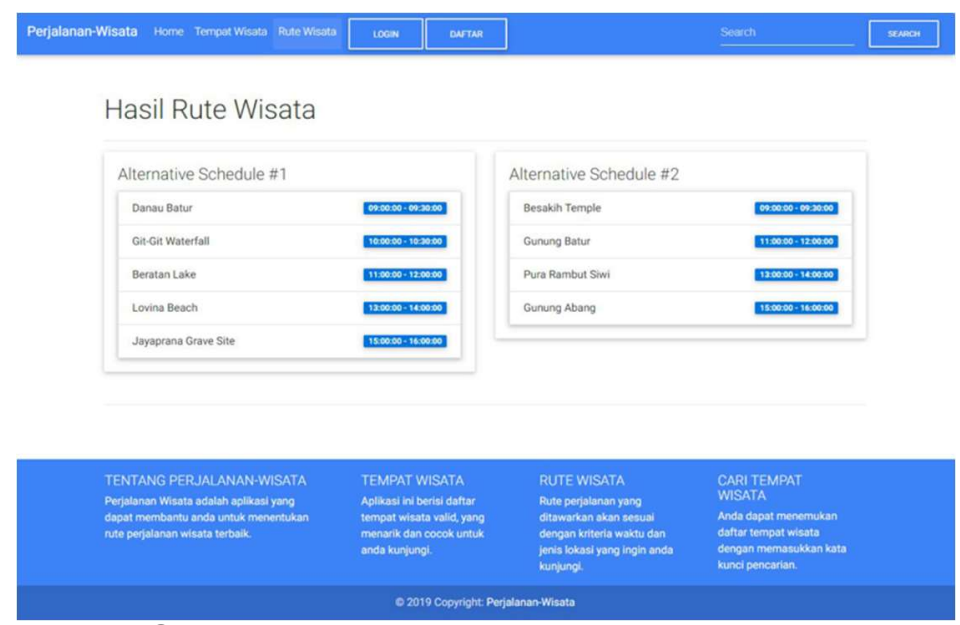

Gambar 3. Hasil Rekomendasi Rute Wisata 


\subsection{Skenario Pengujian dan Analisis}

Pada penelitian ini diuji coba suatu skenario pembuatan trip/rute perjalanan yaitu waktu perjalanan rute yang dibuat 10 jam, maksimum tempat wisata adalah 4 destinasi, maksimum waktu perjalanan 5 jam dan titik awal mulai adalah kawasan sanur. Selanjutnya dari kriteriakriteria tersebut sistem secara otomatis memfiltrasi beberapa destinasi yang memungkinkan untuk dikunjungi. Proses pembuatkan untuk menentukan mana trip/perjalanan terbaik selanjutnya diakomodasi oleh algoritma Genetika.

Selanjutnya pengujian difokuskan kepada kombinasi nilai Crossover Rate $\left(C_{r}\right)$ dan Mutation Rate $\left(M_{r}\right)$. Pergerakan nilai dan batas maksimum dari nilai $C_{r}$ dan $M_{r}$ diadaptasi dari penelitian yang dilakukan oleh Mahmudy, Marian, dan Luong [7], dan penelitian Priandani dan Mahmudy [3] Kombinasi nilai kedua varibael tersebut bergerak dengan kelipatan 0,05 dimulai dari nilai 0 sampai dengan masimum 0,4, dimana jumlah dari $C_{r}$ dan $M_{r}$ adalah 0,4. Sesuai dengan apa yang telah dijelaskan sebelumnya variabel populasi maksimum adalah jumlah kombiasi destinasi yang sesuai atau 100. Jumlah generasi sebanyak 100 menggunakan metode seleksi Roulette Wheels. Uji coba ini dilakukan sebanyak 5 kali untuk setiap kombinasi dari nilai $C_{r}$ dan $M_{r}$.

Hasil pengujian dapat dilihat pada grafik di Gambar 4. Sesuai dengan apa yang terlihat pada Tabel 2. dapat dilihat rata-rata fitness terbaik dihasilkan dari kombiasi nilai $C_{r}=0.25$ dan $M_{r}=$ 0.15 . dan rata-rata nilai fitness yang paling rendah diraih saat nilai $C_{r}=0.4$ dan $M_{r}=0$. Dari grafik pada Gambar 4 terlihat bahwa pada kasus ini dibutuhkan nilai kombinasi antara Mutasi dan Crossover. Dimana kebutuhan akan Crossover sedikit lebih banyak dibandingkan mutasi. Kombinasi diantara Crossover dan Mutasi sangat dibutuhkan dalam kasus ini terbukti jika hanya menjalankan salah satunya maka rata-rata nilai fitness dapat menjadi sangat rendah seperti kasus saat $C_{\mathrm{r}}=0$ dan $M_{\mathrm{r}}=0.4$.

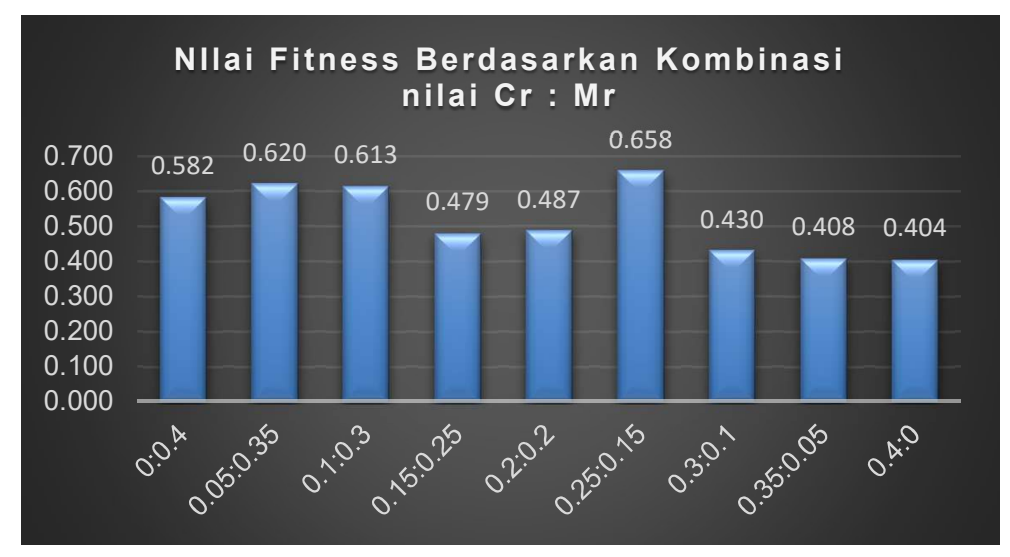

Gambar 4. Grafik Perbandingan Nilai $\mathrm{C}_{\mathrm{r}}$ dan $\mathrm{M}_{\mathrm{r}}$ Terhadap Rata-rata Nilai Fitness

\section{Kesimpulan}

Fitur utama dalam sistem ini adalah sistem dapat menghitung jarak antar destinasi dan mengkombinasikannya untuk memperoleh jalur perjalanan yang paling sesuai dengan kriteria Pengguna. Algoritma Genetika mampu memberikan rekomendasi sesuai prioritas dan kebutuhan-kebutuhan khusus lainya dari pengguna berdasarkan kriteria yang dimasukan. Rekomendasi tersebut dibentuk berdasarkan nilai fungsi tujuan terbaik dari setiap bentuk kombinasi rute perjalanan wisata yang ada. Kejelasan kriteria perjalanan yang diinputkan oleh pengguna maka hasil rekomendasi dari suatu perjalanan akan semakin sesuai dengan keinginan pengguna. Dalam proses pembentukan rute perjalanan wisata yang dibangun berdasarkan algoritma Genetika dapat dilihat bahwa dibutuhkan kombinasi nilai $C_{r}$ dan $M_{r}$ sehingga dapat menghasilkan nilai fitness terbaik.

\section{Saran}

Aplikasi yang dikembangkan dalam penelitian ini dapat memberikan suatu rekomendasi perjalanan wisata sesuai dengan kriteria pengguna secara spesifik. Namun dibeberapa kasus hasil rekomendasi yang dihasilkan antara rekomendasi satu dengan yang lainnya dapat terdiri 
dari kombinasi destinasi-destinasi yang sama namun berbeda urutannya. Secara matematis perhitungan nilai-nilai Fitness yang terbesar memang dapat diraih dengan bentuk rekomendasi rute-rute seperti itu. Hal ini membuat destinasi keragaman kurang beragamnya kombinasi destinasi-destinasi yang lain yang berbeda. Sehingga pada penelitian selanjutnya memungkinkan untuk mengkombinasikan algoritma Genetika dengan algoritma lain sehingga dapat menanggulangi permasalahan tersebut dan menghasilkan kombinasi rute dengan beragam destinasi yang lainnya.

\section{Daftar Pustaka}

[1] A. Murtadho dan M. R. Shihab, "Analisis Situs E-Tourism Indonesia: Studi Terhadap Persebaran Geografis, Pengklasifikasian Situs Serta Pemanfaatan Fungsi Dan Fitur", Journal of Informations Systems, Volume 7, Issues 1, April 2011.

[2] I P. G. H. Suputra. "Implemantasi Algoritma Slope One untuk Rekomendasi Perjalanan Wisata", Prosiding Seminar Nasional Teknologi Informasi dan Aplikasinya, September 2018.

[3] Priandani, N. D. dan Mahmudy, W. F., "Optimasi Travelling Salesman Problem With Time Windows (Tsp-Tw) Pada Penjadwalan Paket Rute Wisata Di Pulau Bali Menggunakan Algoritma Genetika", Seminar Nasional Sistem Informasi Indonesia (SESINDO), 2-3 November 2015.

[4] W. Tanujaya, D. R. S. Dewi, dan D. Endah, "Penerapan Algoritma Genetik untuk Penyelesaian Masalah Vehicle Routing Di Pt.Mif", Jurnal Widya Teknik Vol. 10 No. 1 (92102), 2011.

[5] A. W. Widodo dan W. F. Mahmudy, "Penerapan Algoritma Genetika Pada Sistem Rekomendasi Kuliner", Jurnal IImiah KURSOR Vol. 5 No. 4 Juli 2010.

[6] P. L. L. Belluano, "Optimasi Solusi terbaik dengan Penerapan Non-Dominated Sorting II Algorithm", Jurnal IImiah Ilkom Vol. 8 No. 1 April 2016.

[7] N. L. G. P. Suwirmayanti, I M. Sudarsana, dan S. Darmayasa, "Penerapan Algoritma Genetika untuk Penjadwalan Mata Pelajaran", 2016, Journal Of Applied Intelligent System, Vol. 1 No. 3, 220-233, Oktober 2016.

[8] Mahmudy, W. F., Marian, Romeo M., Luong, Lee H. S., "Modeling and Optimization of Part Type Selection and Loading Problem in Flexible Manufacturing System Using Real Coded Genetic Algorithm", International Journal of Electrical, Computer, Energetic, Electronic and Communication Engineering Vol:7, No:4. 2013. 